\title{
Effect of Foliar-Applied Fertilizers on Pigeonpeas (Cajanus cajan) ${ }^{1,2}$
}

\author{
J. Badillo-Feliciano, R. Abrams, and R. Pietri ${ }^{3}$
}

\begin{abstract}
Two experiments were conducted in a Coto clay (Oxisol) at the Isabela Substation to determine the effect of foliar-applied nutrients on performance of two pigeonpea cultivars. The treatments consisted of foliar-applied Nutrileaf at a rate of $2.24 \mathrm{~kg} / \mathrm{ha}$ at weekly, biweekly, triweekly, and monthly intervals; biweekly applications of equivalent amounts of $\mathrm{N}$ and $\mathrm{P}$ separately and combined as urea and triple superphosphate, respectively; and a check without fertilizer. The data show that foliar-applied nutrients did not have significant effects on green pod yield, plant height, seed weight, protein content, or seed to pod ratio of the two cultivars. Cultivar Kaki yielded more green pods with heavier seeds and grew taller than the experimental line 2BBushy. The seed to pod ratio for 2B-Bushy was higher than that for Kaki, but in both protein content was almost the same.
\end{abstract}

\section{INTRODUCTION}

Pigeonpeas are the major food legume grown commercially in Puerto Rico. Major production areas are in the south, where the crop is usually planted on marginal lands with no fertilizer. The crop has the capability of producing over 6.0 metric tons/ha of green pods 5 . Seeds are about $55 \%$ of the pod weight, with over $22 \%$ protein, $60 \%$ carbohydrates, $1.5 \%$ fats and $3.5 \%$ mineral matter at mature-green stage. The content of $\mathrm{Ca}, \mathrm{P}$, and $\mathrm{Fe}$ is high ${ }^{4}$.

On the basis of the high nutrient content of the seed, it could be inferred that the demand for plant nutrients is correspondingly high and, consequently, a crop response to applied fertilizers would be normally expected. However, Landrau and Samuels ${ }^{6}$, working in a Coto clay (Oxisol) reported a lack of response in yield to different levels of $\mathrm{N}$, $\mathrm{P}$, and K. Pietri et al. (5), working also with a Coto clay, studied the effect of different levels of $\mathrm{N}, \mathrm{P}$, and $\mathrm{K}$ (with and without $\mathrm{Ca}$ ), and of $\mathrm{Mg}$

${ }^{1}$ Manuscript submitted to Editorial Board June 4, 1976.

2 This study was supported by Grant AID/cds-2857.

${ }^{3}$ Associate Agronomist, Plant Breeder, and Professor of Soils, respectively, Agricultural Experiment Station, Mayagüez Campus, University of Puerto Rico, Río Piedras, P.R.

${ }^{4}$ Litzenberger, S. C., ed, Guide for Field Crops in the Tropics and the Subtropics, Pigeon Peas 146-52, 1974.

${ }^{5}$ Pietri, R., Abrams, R., and Juliá, F. J., Influence of fertility level on the protein content and agronomic characters of pigeonpeas in an Oxisol, J. Agr. Univ. P.R. 60(4): 474-77, 1971.

${ }^{6}$ Landrau, P., and Samuels, G., The effects of fertilizer applications on yields of pigeonpeas, J. Agr. Univ. P.R. 43(1): 69-72, 1959. 
and $\mathrm{Ca}$ silicates on pod yield, date of flowering, plant height, seed weight, and protein content. There was no response to the fertilizer treatments.

In view of the results listed above, a different approach to fertilization of pigeonpeas was attempted: foliar nutrient sprays. The approach was based on the hypothesis that an increased amount of readily available nutrients applied at the leaf-absorbing surfaces would modify crop behavior, enhancing yield capability.

\section{MATERIALS AND METHODS}

Two experiments were conducted at the Isabela Experiment Substation farm at $122 \mathrm{~m}$ above sea level, in northwestern Puerto Rico. The soil at the experimental site is classified as Coto, a Tropeptic Haplorthox, clayey, kaolinitic, isohyperthermic. Soil organic matter is $4.2 \% ; \mathrm{pH}, 5.0$; $\mathrm{CEC}, 13.3 \mathrm{meq} / 100 \mathrm{~g}$ of soil; and exchangeable $\mathrm{Ca}, \mathrm{Mg}$ and $\mathrm{K}, 3.6,0.9$ and $0.4 \mathrm{meq} / 100 \mathrm{~g}$ of soil, respectively ${ }^{7}$.

The experimental design followed randomized blocks with eight treatments and six replications. The treatments consisted of foliar-applied Nutrileaf $^{8}$ at a rate of $2.24 \mathrm{~kg} / \mathrm{ha}$ at weekly, biweekly, triweekly, and monthly intervals; biweekly applications of equivalent amounts of $\mathrm{N}$ or $\mathrm{P}$ as urea and triple superphosphate, respectively; a combination of equivalent amounts of $\mathrm{N}$ and $\mathrm{P}$; and a check with no fertilizer.

In the first experiment each plot consisted of six rows $0.98 \mathrm{~m}$ apart and $4.27 \mathrm{~m}$ long with alleys $1.31 \mathrm{~m}$ wide between plots. Pigeonpea cultivar Kaki was planted on July 2, 1974. The seeds were thickly planted and then thinned to three plants per linear meter. Prometryne was applied as a pre-emergent herbicide at the rate of $3.33 \mathrm{~kg} / \mathrm{ha}$. Treatment differentials were initiated when plants were 8 weeks old and continued until October 30, 1974. The plants were sprayed with Thiodan, at the rate of $1.12 \mathrm{~kg} / \mathrm{ha}$, during pod formation to control pod borers. Twenty plants from the inner rows were harvested; pods were hand picked twice during the harvesting season.

The second experiment differed from the first one in that experimental line 2B-Bushy, a determinate flowering type, was used. The plots consisted of six rows $0.46 \mathrm{~m}$ apart and $3.35 \mathrm{~m}$ long. It was planted on October 9, 1974 and harvested on February 2, 1975. Foliar sprays were

\footnotetext{
${ }^{7}$ Beinroth, F. H., The Natural Environment of Puerto Rico, Univ. P.R. Coll. Agr Sci., 1972.

${ }^{8}$ Trade names are used in this publication solely for the purpose of providing specific information. Mention of a trade name does not constitute a guarantee or warranty of equipment or materials by the Agricultural Experiment Station of the University of Puerto Rico or an endorsement over other equipment or materials not mentioned.
} 
initiated on December 6, 1974 and continued until January 6, 1975. The inner four rows were harvested once only.

The following measurements were made and the data submitted to analyses of variance: pod yield, tons/ha; plant height, $\mathrm{cm}$ from soil surface to top of stem; seed size, weight in grams of 100 seeds; protein content (percentage of $\mathrm{N}$ multipled by 6.25 ) reported on a dry weight basis as percentage of crude protein; and seed to pod ratio.

TABLE 1. -Effect of foliar-applied fertilizer on pigeonpeas

\begin{tabular}{|c|c|c|c|c|c|c|}
\hline Treatments & Sprays & Yield & $\begin{array}{l}\text { Plant } \\
\text { height }\end{array}$ & $\begin{array}{l}\text { Protein con- } \\
\text { tent }\end{array}$ & $\begin{array}{l}\text { Weight of } \\
100 \text { seeds }\end{array}$ & $\underset{\text { ratio }}{\text { Grain pod }}$ \\
\hline & No. & Tons/ha & $\mathrm{Cm}$ & Percent & $G$ & \\
\hline \multicolumn{7}{|c|}{ Cultivar Kahi } \\
\hline $\begin{array}{l}\text { Nutrileaf, weekly, } 2.24 \mathrm{~kg} / \\
\text { ha }\end{array}$ & 9 & $10.00 \mathrm{a}^{1}$ & $237.1 \mathrm{a}$ & $22.0 \mathrm{a}$ & $25.5 \mathrm{a}$ & $.55 \mathrm{a}$ \\
\hline $\begin{array}{l}\text { Nutrileaf, biweekly, } 2.24 \\
\text { kg ha }\end{array}$ & 5 & $9.65 \mathrm{a}$ & $240.8 \mathrm{a}$ & $21.4 \mathrm{a}$ & $37.2 \mathrm{a}$ & $.56 \mathrm{a}$ \\
\hline $\begin{array}{l}\text { Nutrileaf, triweekly, } 2.24 \\
\mathrm{~kg} / \mathrm{ha}\end{array}$ & 3 & $9.80 \mathrm{a}$ & $236.3 \mathrm{a}$ & $22.4 \mathrm{a}$ & 37.1 a & $.55 \mathrm{a}$ \\
\hline $\begin{array}{l}\text { Nutrileaf, monthly, } 2.24 \\
\text { kg/ha }\end{array}$ & 3 & $9.24 \mathrm{a}$ & $241.3 \mathrm{a}$ & 22.1 a & $36.8 \mathrm{a}$ & $.55 \mathrm{a}$ \\
\hline $\begin{array}{l}N \text { equivalent (urea), bi- } \\
\text { weekly }\end{array}$ & 5 & $11.71 \mathrm{a}$ & $235.5 \mathrm{a}$ & $22.4 \mathrm{a}$ & $38.1 \mathrm{a}$ & $.55 \mathrm{a}$ \\
\hline $\begin{array}{l}\text { P equivalent (triple super- } \\
\text { phosphate), biw cekly }\end{array}$ & 5 & $9.83 \mathrm{a}$ & $242.3 \mathrm{a}$ & $21.6 \mathrm{a}$ & $36.0 \mathrm{a}$ & $.56 \mathrm{a}$ \\
\hline $\begin{array}{l}\mathrm{P}+\mathrm{N} \text { equivalents, bi- } \\
\text { weekly }\end{array}$ & 5 & $10.40 \mathrm{a}$ & $237.1 \mathrm{a}$ & $21.9 \mathrm{a}$ & $37.9 \mathrm{a}$ & $.56 \mathrm{a}$ \\
\hline No fertilizer & & 9.94 & $236.1 \mathrm{a}$ & $22.1 \mathrm{a}$ & $38.6 \mathrm{a}$ & $.56 \mathrm{a}$ \\
\hline \multicolumn{7}{|c|}{ Cultivar 2B-Bushy } \\
\hline $\begin{array}{l}\text { Nutrileaf, weekly, } 2.24 \\
\mathrm{~kg} / \mathrm{ha}\end{array}$ & 5 & $3.88 \mathrm{a}$ & 86.7 a & $22.7 \mathrm{ab}$ & $31.0 \mathrm{a}$ & $.62 \mathrm{a}$ \\
\hline $\begin{array}{l}\text { Nutrileaf, jiweekly, } 2.24 \\
\text { kg/ha }\end{array}$ & 3 & $3.82 \mathrm{a}$ & $84.6 \mathrm{a}$ & $22.0 \mathrm{ab}$ & 30.5 a & $.62 \mathrm{a}$ \\
\hline $\begin{array}{l}\text { Nutrileaf, triweekly, } 2.24 \\
\mathrm{~kg} / \mathrm{ha}\end{array}$ & 2 & $4.16 \mathrm{a}$ & $93.2 \mathrm{a}$ & $22.0 \mathrm{ab}$ & $30.2 \mathrm{a}$ & $.61 \mathrm{a}$ \\
\hline $\begin{array}{l}\text { Nutrileaf, monthly, } 2.24 \\
\mathrm{~kg} / \mathrm{ha}\end{array}$ & 2 & $3.70 \mathrm{a}$ & $84.3 \mathrm{a}$ & $22.6 \mathrm{ab}$ & $30.6 \mathrm{a}$ & $.62 \mathrm{a}$ \\
\hline $\begin{array}{l}\mathrm{N} \text { equivalent (urea), bi- } \\
\text { weekly }\end{array}$ & 3 & $4.18 \mathrm{a}$ & $87.9 \mathrm{a}$ & $21.3 \mathrm{~b}$ & $29.4 \mathrm{a}$ & $.60 \mathrm{a}$ \\
\hline $\begin{array}{l}\text { P equivalent (triple super- } \\
\text { phosphate), biweekly }\end{array}$ & 3 & $4.16 \mathrm{a}$ & $86.4 \mathrm{a}$ & $21.9 \mathrm{ab}$ & $33.6 \mathrm{a}$ & $.63 \mathrm{a}$ \\
\hline $\begin{array}{l}\mathrm{P}+\mathrm{N} \text { equivalents, bi- } \\
\text { weekly }\end{array}$ & 3 & $3.27 \mathrm{a}$ & 84.3 a & $22.0 \mathrm{ab}$ & $29.9 \mathrm{a}$ & $60 \mathrm{a}$ \\
\hline No fertilizer & - & $4.01 \mathrm{a}$ & $94.2 \mathrm{a}$ & $22.8 \mathrm{a}$ & $32.9 \mathrm{a}$ & $.62 \mathrm{a}$ \\
\hline
\end{tabular}

${ }^{1}$ Values with a letter or letters in common do not differ significantly at the $5 \%$ level. 


\section{RESULTS AND DISCUSSION}

Table 1 gives data on the effect of foliar-applied nutrients on yield, plant height, seed weight, protein content, and pod to seed ratio from experiments, for cultivar Kaki and line 2B-Bushy, respectively. Mean yields of Kaki from the fertilized plots were not significantly different from those of the unfertilized plots.

There were no significant differences in plant height, protein content, weight of 100 seeds, and seed/pod ratio attributable to treatments.

Data from the second experiment show that fieldwide average yields from experimental line 2B-Bushy, as expected, were lower than those from the Kaki cultivar, because Kaki is indeterminate with a longer vegetative growth period than 2B-Bushy, which is determinate and semi-dwarf. In general, yields followed the same trend as in experiment 1. Here again, there were no significant differences in yields.

The information obtained from this study confirms previous findings of Landrau and Samuels (6) and Pietri et al. (5) that pigeonpeas, when planted on a Coto clay, do not respond to fertilization. Being a legume, pigeonpeas seem to fix, in association with Rhizobium, sufficient nitrogen for bearing a normal crop. It further seems that the requirements of other major nutrients, for all the characteristics studied are low or that the unfertilized Coto clay (Oxisol) is able to meet pigeonpea nutrient requirements. Also, it is apparent that the deep and extensive root system developed by pigeonpea during its growth enable it to absorb essential nutrients in sufficient amounts for normal crop production.

\section{RESUMEN}

El objetivo de este estudio fue determinar si la aplicación de nutrimentos a las hojas afectaban la producción de vainas verdes, la altura de la planta, el peso de las legumbres, el porcentaje de proteína y la razón semilla:vaina en dos cultivares del gandur. Se realizaron dos experimentos en un suelo Coto arcilloso (Oxisol) en la Subestación Experimental de Isabela. Se utilizó un diseño experimental de bloques completos con 8 tratamientos repetidos 6 veces. Los tratamientos consistieron de aplicaciones foliares de Nutrileaf a razón de $2.24 \mathrm{~kg}$./ha. a intervalos de 1, 2, 3, y 4 semanas; aplicaciones quincenales individuales de $\mathrm{N}$ y $\mathrm{P}$ en cantidades equivalentes en forma de urea y superfosfato triple, respectivamente y también applicaciones combinadas de $\mathrm{N}$ y $\mathrm{P}$. Además, se incluyó un testigo que no recibió abono. Los datos demuestran que las aplicaciones foliares de Nutrileaf no tuvieron efecto significativo en la producción de vainas verdes, altura de la planta, peso de 100 semillas, porcentaje de proteína y razón semilla:vaina. 